Tér és Társadalom 23. évf. 2009/4. 241-244. p.

Tér és Társadalom

XXIII. évf. 2009 4: 241-254

KÖNYVJELZÖ

\title{
GILLES DURANTON - PHILIPPE MARTIN - THIERRY MAYER - FLORIAN MAYNERIS: LES POLES DE COMPETITIVITE. QUE PEUT-ON EN ATTENDRE?
}

\author{
(Éditions Rue d'Ulm-Présses de l'École Normale Supérieure, \\ Párizs, 2008. 82 o.) \\ CSÁK LÁSZLÓ
}

„a területfejlesztés...müvészet, nem tudomány vagy gyakorlat”

Gravier: Párizs és a francia sivatag

A CEPREMAP (Centre pour la Recherche Economique et ses Applications) multidiszciplináris alkalmazott gazdaságtani kutatási tevékenységének keretében megjelent kötet, mely a francia versenyképességi pólusokat veszi górcső alá, kiváló alkalmat nyújt arra, hogy az olvasó mintegy distanciálódva tekintsen a francia területfejlesztés jelenére. Arra a jelenre, ami az immár legalább hatvankét esztendeje formálódó tevékenységek eredménye. Nyilván magyarázatra szorul már maga a hatvankét év is, hiszen a szakmai köztudatban a négy évtizede múködö DIACT (DATAR 1963 és 2006 között) megalakulásától szokás számítani a par excellence területfejlesztés kezdetét. Azonban nyilván nem tekinthetünk el a DATAR elött már müködő szervezetektöl, mint a DAT, s akár 1944-ig is visszamehetünk, hiszen már a Vichy-korszakban müködött egy kifejezetten és kimondottan területfejlesztéssel foglalkozó intézmény, a DGEN (Delegation general a l'equipment national) (Brunham 2009). A korai és a történelmi események okán nyilván ki sem bontakozó kezdeményezések után az egyébként a Vichy-kormánynak is dolgozó Jean-Francois Gravier 1947-es Párizs és a francia sivatag címủ írásának megjelenésétől számítható megítélésünk szerint a francia területfejlesztés máig elö története.

Jelen recenzió tárgya azért érdemel kitüntetett figyelmet, mert kiváló lehetóséget ad arra, hogy átgondolja az olvasó - nem is csupán a kötet címét adó témát, sokkal inkább - a területfejlesztési diskurzus belsô, feszítő kérdéseit, esetleges ellentmondásait. A kötet bevezetỏjében máris élesen szembeállítja a területfejlesztési politikát (a szerzők ötven éves történetként tekintenek rá) és a klaszter politikát, utalva a napjainkban is folyó meglehetösen vehemens vitákra, melyek a területfejlesztési politika megújítását kiharcolók és a hagyományos szempontokat védelmezők közt 
dúlnak. A kötet röviden „intézi el” a területfejlesztés meghatározását, amennyiben így fogalmaz: „olyan gazdaság-földrajzi helyzetre összpontosít túlzott mértékben, mely szerint néhány régió túlzottan gazdag és a hanyatló régiókat segíteni kell" (12. o.). Sommás és nyilván leegyszerüsítỏ megfogalmazás, amit talán az is indokolhat, hogy a kötet célja nem csupán a szük szakmai körökben kifejteni a szerzők nézőpontját, de kifejezetten értelmes üzeneteket kíván közvetíteni a nagyközönségnek és a döntéshozóknak is.

A klasztereket és a versenyképességi pólusokat gyakorlatilag szinonimákként használja kötet, ami nyilván nem egészen megengedhető, hasznosabb volna úgy fogalmazni, hogy a francia pólus-politikát a klaszter-elméletek inspirálták (Monodde Castelbajac 2008). Azonban, hogy keril a csizma az asztalra, avagy miként tör be a kalszter-elmélet a területfejlesztési diskurzus terébe, hogyan válik ott meghatározó (politikai) céllá és milyen eszközök, milyen hatékonysággal rendelődnek hozzá a célokhoz? - ezekre a kérdésekre részletes és lényegre törő válaszokat kapunk a kötetben, melynek felépítése igen jól átlátható, néhol már-már didaktikus, s magán viseli a projekteknél szokásos „,inal report”-ok jegyeit is, így pl. a példákat ismertető szövegdobozokat.

A francia pólus-program keretében, már az első, három éves szakaszban is jelentős forrást különítettek el különböző támogatási formák számára, kiemelten az innovációs együttmüködések $(\mathrm{K}+\mathrm{TF})$ beindítására és a kutatás-fejlesztéssel foglalkozó szervezetek adókedvezményeinek biztosítására. Az immár 71 versenyképességi pólusban megvalósuló program jelenleg „Poles 2.0” néven fut, és teljes költségvetése másfél milliárd euró. Meg kell említeni a területfejlesztés iránt érzékeny olvasók számára, hogy ezzel párhuzamosan - nyilván jóval szerényebb feltételeket biztosítva - kialakításra került a pólusok ,kistestvéreinek” (Monod-de Castelbajac 2008), azaz a vidéki kiválósági pólusoknak a rendszere is.

A 2005-2008-as időszakot megelőzően is történt egy jelentős próbálkozás a klaszter-szemlélet Franciaországi meghonosítására, jelesül a SPL-program (systemes productifs locaux), melynek eredményeit szintén részletesen és igen kritikusan elemzi a kötet. Maguk a SPL-ek, ha úgy tetszik, nagyon is hagyományos területfejlesztési jellegú kalszter-kezdeményezések voltak, amennyiben a támogatásokhoz kifejezetten csak hanyatló régiókban működő rendszerek fértek hozzá. A kutatók megállapítása szerint a közpénzek felhasználásának hatékonyságáról csak annyit mondhatunk el, hogy a kiválasztási kritériumok szerint eleve nagyobb az átlagos vállalat-méret és nagyobb az export-képességük, ugyanakkor a versenyképesség tekintetében mérvadó termelékenységi mutatójuk valamivel rosszabb, mint az SPL-programból kimaradó vállalatoké. Általában is arra a következtetésre jutottak a szerzők, hogy az SPL-program kedvezményezettjeinek versenyképessége nem javult, $\mathrm{s}$ talán azt feltételezhetjük, hogy támogatás híján romlottak volna mutatóik - ezt azonban nem lehet igazolni, csak feltételezni. Az azonban statisztikailag szignifikáns módon kimutatható, hogy az SPL-hez való csatlakozás okán termelékenységük romlott, ami legalábbis elgondolkodtató. 
Elvileg a Poles 2.0 már tisztán versenyképességi célokat szolgálna, hozzátéve, hogy azt azért meglehetôsen nehéz elképzelni, hogy Franciaországban 71 valódi klaszter jöhetne létre. A francia klaszter-világ egyébiránt igen színes, hiszen az 1300 vállalkozást magában foglaló Aerospace Valley-től a Choletais térségben múködő Le Pole Enfant-ig igen sokféle méretü, szerkezetủ és múködésủ klaszter található. Jelen kötet szerzői azonban az SPL és az első pólus-program tapasztalatai alapján szkeptikusak az eredményesség tekintetében. Az SPL-ekröl már idéztük véleményüket, azonban igen fontos és a közép-európai pólus-politikák tervezői számára is érdekes megjegyzéseket tesznek. Ugyanis a francia klaszterek kapcsán megállapítják, hogy azok igen ritkán érik el az úgynevezett kritikus tömeget, egészen pontosan úgy fogalmaznak, hogy a francia klaszterek „túl kicsik” - márpedig a klaszterek esetében, nyilván a klasztert alkotó szervezetek tevékenységi körétől, az adott iparág vagy szolgáltatás jellegétől függoonen, de mégis a méret a lényeg. Ellenkező esetben az agglomerációs előnyök nem vagy alig jelentkeznek, s akkor mi végre a klaszteresedés, hacsak nem a költségvetési források lehívása az egyedüli cél.

A klaszterek mérete tehát túl kicsi, s ezen a ponton máris szembesülhetünk a francia terïletfejlesztés dilemmájával. A már a mottóban is idézett Gravier-szöveg, mely mintegy területfejlesztési kiáltványnak is tekinthető, azaz a Párizs és a francia sivatag (Alvergne-Musso 2008), ugyanis éppen abban látja a területfejlesztés múvészetének szükségességét, hogy le kell győzni a város, azaz Párizs túlsúlyát. A teriletfejlesztés ebben az összefüggésben még nem policentrikus jellegü, hanem inkább a lehetôségekhez képest homogén térstruktúra kialakítását célzó megközelítés. A közszolgáltatásokhoz, a megfelelő életminőséghez hozzá kell férnie ugyanis minden franciának, éljen bár Párizsban vagy valamelyik hegyvidéki faluban. Azaz, ha a klaszterek túl kicsik, s így nagyobbakká kell lenniük, egyértelmü, hogy a számuk is kisebb lesz, azaz néhány jelentős központ jön létre, a többi térség pedig leszakad. Ez egyértelmủen a (francia) területfejlesztési alapelvek ellen való vétek volna, hiszen így csak oázisok jönnének létre, de a sivatag marad.

Ugyanakkor a szerzők helyesen rámutatnak arra, hogy a francia gazdaság jellemzöiből adódik, hogy a klaszterek túl kicsik. Megítélésük szerint a méretbeli hátrányok kialakulásának oka, hogy a vállalkozások, a munkaeró és a tudás mobilitása meglehetösen alacsony Franciaországban, azaz nem megy végbe a koncentráció. Koncentráció hiányában pedig a klaszter kicsi lesz, s így az agglomerációs elönyök nem jelennek meg, a pozitív externáliákat nem lehet interiorizálni, mivel nem jönnek létre. Persze ez a 22-es csapdája, hiszen adott esetben a telephely-áthelyezést mérlegelő vállalat mondhatja azt is, hogy nem választom a túl kicsi klasztert, hiszen nincs agglomerációs elöny, amit kihasználhatnék - így pedig az agglomerációs elönyök még annyira sem jönnek létre. A szerzők azonban rámutatnak, hogy a vállalati telephely-áthelyezési döntések elókészítése során amúgy sem végeznek számításokat a pozitív externáliákra vonatkozóan, azaz a klaszteresedés elönyei vállalati öszszefüggésben aligha mérvadóak.

A méretbeli problémák okára lehetne hatékonyan választ találni, ahogy azt a kötet ki is emeli, azonban a mobilitás feltételeinek megteremtése esetén, ami már ön- 
magában is térgazdaságtani közhely, a polarizáció erősödik. A szerzők is úgy fogalmaznak, hogy a közpénzek hatékony felhasználását az jelentené, ha nem a következményekkel foglalkoznának, hanem a kiváltó okokat kezelnék, azonban ezáltal a klaszterek világa egyértelmủen nyertesekre és vesztesekre tagolódna, azaz valóban a polarizálódást erősítené a beavatkozás. Ebben az értelemben beszélhetünk öszinte pólus-politikáról, ami a mobilitási szempontokat is figyelembe veszi, s számol azzal, hogy nem lehet minden klaszter nagy, ugyanakkor folytatható a kispólusok önellentmondást tartalmazó támogatása is, ami nyilván aligha lehet hatékony.

Descartes filozófiája szerint, mely máig meghatározza a francia gondolkodást (Glucksmann 1987) a dolgokat tisztán és elkülönítetten kell felfogni, s amennyiben így teszünk, helyes értelmezéshez juthatunk. Látható, s ez a kötet igen kiemelkedő üzenete, hogy a versenyképesség és a területfejlesztés kérdését elkülönítetten kell kezelni, ellenkezỏ próbálkozások jellemzően nem hatékony beavatkozásokhoz vezethetnek. A szerzők egyértelmủen állást foglalnak a (hagyományos) területfejlesztéstöl mentesített területi tervezés mellett, s a klaszterek központi, állami támogatása helyett a helyi szintủ cselekvést tartják hatékonyabbnak, amit megerősít a „természetes" klaszterek sikeressége, ugyanakkor a koncentráció negatív externáliáinak csökkentésében látják a valódi és legitim beavatkozási területet a közszféra számára.

\section{Irodalom}

Alvergne, Ch.-Musso, P. (eds.) (2008) Les grands textes de l'amenagement du territoire et de la decentralisation. La documentation francaise, Párizs.

Brunham, J. (2009) Politicans, Bureaucrats and Leadership in Organizations. Lessons from Regional Planning in France. Palgrave Macmillan, New York.

Glucksmann, A (1987) Descartes, c'est la France. Flammarion, Párizs.

Monod, J,-de Castelbajac, Ph. (2008) L'amenagament du territoire. PUF, Párizs. 